\title{
Transmission of syphilis between sexual partners in Gabon
}

\author{
D SCHRIJVERS, ${ }^{*}$ R JOSSE, $\dagger$ A TREBUCQ,$\dagger$ A DUPONT,$*$ H CHERINGOU $\ddagger$ \\ B LAROUZÉ§
}

From the *Centre International de Recherches Médicales de Franceville (CIRMF), Franceville, Gabon; the †Organisation de Coordination pour la Lutte contre les Endémies en Afrique Centrale (OCEAC), Yaounde, Cameroun; the $\ddagger$ Service des Grandes Endémies, Franceville, Gabon; and the §Hôpital Claude Bernard, Institut Leon M'Ba, Paris, France

SUMMARY The prevalence and transmission of syphilis was studied in a semirural community in south eastern Gabon. The overall prevalence was $8 \%(99 / 1251)$ and there was no difference in age adjusted prevalence between men and women. The transmission of syphilis between sexual partners occurred in $18 \cdot 1 \%(8 / 44)$.

Syphilis is one of the most prevalent sexually transmitted diseases (STD) in the developing countries, ${ }^{2}$ and it has a considerable impact on the outcome of pregnancy and on perinatal morbidity. ${ }^{3}$ Evidence that genital ulceration can be a risk factor for developing AIDS, ${ }^{4}$ and the occurrence of genital ulcers in patients with primary syphilis, makes the high prevalence of syphilis in a population a serious community health problem. We have reported high prevalences of syphilis in Gabon, ${ }^{5}$ a western equatorial African country. In this study we report on the prevalence of syphilis in a semirural community in south eastern Gabon and the transmission of this disease between sexual partners.

Patients, materials, and methods

In April 1988 we performed a community survey in the city of Franceville, a semirural community consisting of 48 townships in south eastern Gabon. All 1251 people living in five of these townships at the time of the survey were included in the study. A house to house visit was undertaken by an epidemiological team, which listed all members of each household. Information on sex, age, and familial relationship was gathered and a $10 \mathrm{ml}$ blood sample taken from each

\footnotetext{
Address for reprints: Dr Dirk Schrijvers, Universitaire Instelling Antwerpen, Departement Epidemiologie en Sociale Geneeskunde, Universiteitsplein 1, B-Wilrijk, Belgium
}

Accepted for publication 25 September 1988 person. Several visits were made to each household to include as many members as possible.

All serum samples were screened for treponemal infection by the semiquantitative Venereal Diseases Research Laboratory (VDRL) test (Diagnostics Pasteur), and positive results were confirmed by the quantitative Treponema pallidum haemagglutination assay (TPHA) (Behring Diagnostics). Agglutination at a titre of $1 / 80$ or more in the TPHA was considered to show a positive result.

Comparison of groups was by $\chi^{2}$ analysis and by Student's $t$ test. Geometric mean titres and indirect standardisation were calculated using standard methods. ${ }^{6}$

\section{Results}

Of 1251 people included in the serological survey, 99 $(8 \%)$ had positive results to treponemal serology tests. The table shows the distribution of treponemal infection in relation to age and sex. The proportion of the two sexes differed in different age groups; significantly $(\mathrm{p}<0.025)$ more of the 440 people aged 15-29 were women $(269,61 \cdot 1 \%)$ than men $(171,38.9 \%)$. No significant difference in age adjusted prevalence of syphilis was seen between men and women in the total population, but in those aged $\mathbf{4 0}$ or over a significantly $(\mathrm{p}<0.05)$ smaller percentage of women $(31 / 178$, $17 \cdot 4 \%)$ than men $(35 / 128,27 \cdot 3 \%)$ hàd treponemal infection.

The prevalence of syphilis increased in relation to age from $1 \%(4 / 385)$ in the youngest (14 or younger) to 
Table Distribution of treponemal infection in 1251 people in relation to age and sex

\begin{tabular}{|c|c|c|c|c|c|}
\hline \multirow[b]{2}{*}{ Age (years) } & \multicolumn{2}{|c|}{ Men } & \multicolumn{2}{|c|}{ Women } & \multirow[b]{2}{*}{ Difference } \\
\hline & $n$ & $\begin{array}{l}\text { No (\%) } \\
\text { positive }\end{array}$ & $n$ & $\begin{array}{l}\text { No (\%) } \\
\text { positive }\end{array}$ & \\
\hline $\begin{array}{l}0-14 \\
15-19 \\
20-29 \\
30-39 \\
40 \text { or older }\end{array}$ & $\begin{array}{r}189 \\
79 \\
92 \\
59 \\
128\end{array}$ & $\begin{array}{rr}1 & (0.5) \\
2 & (2.5) \\
2 & (2 \cdot 2) \\
8 & (13.6) \\
35 & (27.3)\end{array}$ & $\begin{array}{r}196 \\
97 \\
172 \\
61 \\
178\end{array}$ & $\begin{array}{rr}3 & (1.5) \\
1 & (1.0) \\
9 & (5.2) \\
8 & (13.1) \\
31 & (17.4)\end{array}$ & $\begin{array}{l}\text { NS } \\
\text { NS } \\
\text { NS } \\
\text { NS } \\
p<0.05\end{array}$ \\
\hline Total & 547 & $47 \quad(8 \cdot 6)$ & 704 & $52 \quad(7 \cdot 4)$ & \\
\hline $\begin{array}{l}\text { Age adjusted } \\
\text { prevalence }\end{array}$ & & $(9 \cdot 0)$ & & $(7 \cdot 2)$ & NS \\
\hline
\end{tabular}

$21.5 \%(66 / 306)$ in the oldest (40 or older). In the youngest group three girls, aged 10,11 , and 12 , had positive results to treponemal serology tests, but had no clinical signs of yaws.

We were able to test the sexual partners of 44 people with positive treponemal serology results. Eight $(18.1 \%)$ of their partners also had positive results. No age difference was seen between the patients with positive partners (mean age 59) and those with negative partners (mean age 54). When the geometric mean (SD) titres in the TPHA of the two groups were compared, the titre was higher $(1 / 830(0 \cdot 224))$ in the eight whose partner was positive than in the other 36 $(1 / 457(0.389))$, but the difference was not significant.

\section{Discussion}

The $8 \%$ prevalence of treponemal infection confirms the prevalence reported in our study of the general population in the same area. ${ }^{5}$ As yaws is not seen in the study area (Dr Hamono, Ministry of Public Health, Gabon, unpublished observation), treponemal infection is mainly transmitted sexually. The steady increase in incidence with age in people over 19 supports this statement.
The transmission of syphilis between sexual partners occurred in $18.1 \%$ of the 44 couples in which one partner had a positive result. This transmission rate was low compared with figures given by Schober et al, ${ }^{7}$ who found positive results in $58 \%$ of heterosexual contacts of patients attending a STD clinic in the United Kingdom. Our study population, however, was not a selected one consisting of people attending with clinical signs, so we probably included people in whom infection had lasted longer or who had received treatment but were still positive. We saw a higher, though not significantly higher, transmission rate in people with agglutination at higher titres in the TPHA, which could also have shown that the disease was in an earlier stage and therefore probably more contagious than in people with agglutination at lower titres.

In conclusion, the transmission of syphilis between sexual partners was fairly rare in our study population.

\section{References}

1 Osoba AO. Sexually transmitted diseases in tropical Africa. A review of the present situation. British Journal of Venereal Diseases 1981;57:89-94.

2 Piot P, Meheus A. Epidémiologie des maladies sexuellement transmissibles dans les pays en déloppement. Ann Soc Belge Med Trop 1983;63:281-311.

3 Brunham RC, Holmes KK, Eschenbach D. Sexually transmitted diseases in pregnancy. In: Holmes KK, Mårdh P-A, Sparling PF, Wiesner PJ, eds. Sexually transmitted diseases. New York: McGraw Hill, 1984:782-811.

4 Greenblatt R, Lukehart S, Plummer F, et al. Genital ulceration as a risk factor for human immunodeficiency virus infection. AIDS 1988;2:47-9.

5 Dupont A, Schrijvers D, Delaporte E, et al. Seroprevalence of treponemal infection among randomized representative urban and semi-rural Gabonese populations (western equatorial Africa). Bull Soc Pathol Exot Filiales 1988;81:699-704.

6 Armitage P. Statistical methods in medical research. Oxford: Blackwell Scientific, 1971:388-91.

7 Schober P, Gabriel G, White P, Felton W, Thin R. How infectious is syphilis? British Journal of Venereal Diseases 1983;59:217-9. 